\title{
Experimental study on pyrolysis water used as lignite molding water
}

\author{
Xiaonan Zhao ${ }^{1,2}$ a Li Ding $^{1,2 b}$, Erqiang Su ${ }^{1,2 ~ c}$, Shunli Zhang ${ }^{1,2 ~ d, ~}$ \\ andDaohong $\mathrm{Wu}^{1,2 \mathrm{e}}$ \\ ${ }^{1}$ Beijing Shenwu Environment \& Energy Technology Co., Ltd., Beijing, China 102200 \\ ${ }^{2}$ Pyrolysis and Quality Engineering Technology Research Center of Low Rank Coal and Organic \\ Waste in Beijing city, Beijing 102200 \\ azhaonan354@163.com, bdingli@shenwu.com, 'suerqiang@shenwu.com, \\ dzhangshunli@shenwu.com, 'wudaohong@shenwu.com
}

\begin{abstract}
Keywords: Lignite; molding coal; pyrolysis water; pyrolysis characteristics Abstract. The influence of pyrolysis water which was used as molding water of powdered coal on molding coal pyrolysis conversion rate and semi-coke strength was experimentally researched in the pyrolysis experimental device independently developed by Beijing Shenwu Environment \& Energy Technology Co., Ltd,. The experimental results were showed that pyrolysis water can enhance the strength of the semi-coke, increase $\mathrm{CH}_{4}$ and $\mathrm{H}_{2}$ componentcontent of pyrolysis gas, improve yield and quality of tar. Tar yield in the pyrolysis process of molding coal used pyrolysis water as molding water(MCPW) was 1.4 times than that of molding coal used new water as molding water(MCNW), and the content of light oil in pyrolysis of MCPW was higher.
\end{abstract}

\section{Introduction}

According to international geologists, lignite, accounting for about $40 \%$ of the world's total coal reserves, is one of the main sources of energy that can be used in the future. The lignite resources in china are very rich, proved reserves of lignite accounted for $12.69 \%$ of the country's proven reserves of resources. Compared with foreign lignite, China's lignite quality is uneven, mainly for the high ash, low calorific value, processing and utilization of poor economic. In the future, how to make use of lignite resources scientifically, reasonably and fully will be of great significance to the sustainable development of coal industry.

Lignite has the characteristics of high moisture content, high volatile, low calorific value, easy to powder, and the direct utilization efficiency is low. With the improvement of the mechanization degree of coal mining, in the course of mining the content of coal powder in raw coal accounted for generally $40-60 \%$. Due to the low intensity of lignite, there is serious pulverization phenomenon in the drying process, according to the experimental data, in the process of drying the powder rate is in the range of 20-30\%. Pyrolysis can improve the quality of lignite, however, it is found that a lot of pyrolysis water is produced during the pyrolysis process, the pyrolysis water contains a certain amount of sulfide, cyanide and other impurities, its cannot be recycled, and the cost of sewage treatment is high. There exist in some of the tar in low temperature pyrolysis wastewater, the oil according to the existing form can be simply divided into floating oil, dispersing oil, emulsified oil, dissolved oil and heavy oil, in which the proportion of heavy oil and floating oil only account for around 5\%, and the proportion of dispersing oil, emulsified oil and dissolved oil is over 90\% (which accounted for $90 \%$ of the oil content in wastewater).

Pyrolysiswater of low temperature coal of typical lignite contains $\mathrm{COD}, \mathrm{BOD}, \mathrm{NH}_{4}-\mathrm{H}$, volatile phenols etc., and its $\mathrm{pH}$ value is higher than 7. In order to reduce the cost and environmental pollution, the experiment was to design to investigate the feasibility of using pyrolysis water as lignite molding water, and the effect of pyrolysis water on the pyrolysis products was studied. 


\section{Experimental method}

This low temperature pyrolysis experimental device in the paper was shown in Fig.1, and its processing capacity was $3 \mathrm{~kg}$ per time. The device was mainly composed of reaction system, oil and water condensation system, pyrolysis gas measurement and instrument control system.

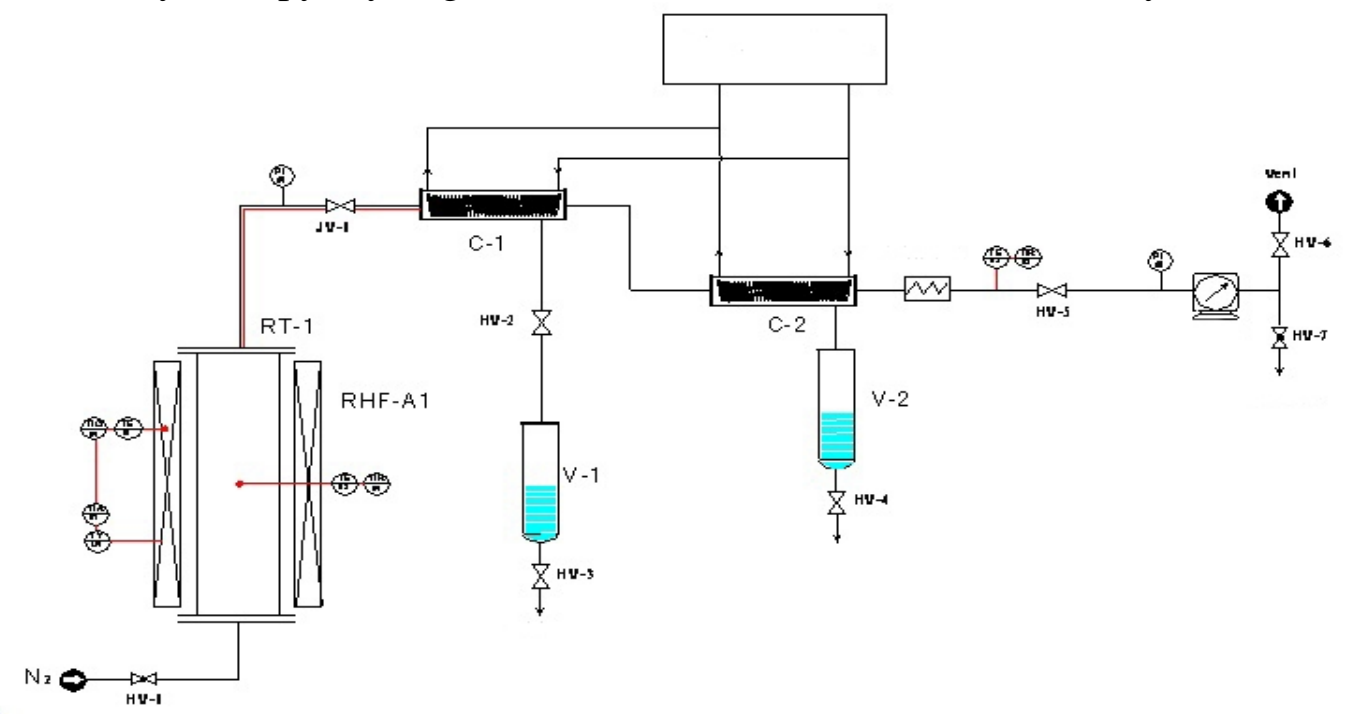

Fig. 1 pyrolysis process diagram

The process of this experiment was as follows: coal sample was fed into the fixed bed reactor after molding, purged the reactor using nitrogen, set the pyrolysis temperature, heating rate and residence time, recorded the initial value of wet-type flow meter, and then started the experiment. Volatile product was condensed by condensing system, oil/water mixture into the liquid storage tank, and pyrolysis gas discharged from the condenser into the wet-type flow meter. After the experiment was finished, shut off the heating furnace, recorded wet-type flow meter date. The oil/water mixture was separated. Weighted the char after the reactor temperature was lower than $50^{\circ} \mathrm{C}$.

The lignite from Inner Mongolia was chosen as the coal samples for this experiment whose particle size fraction was $0-5 \mathrm{~mm}$. Material mixed of the broken, screened and dried coal powder with pyrolysis water, prepared of coal briquette, and tested of coal mechanical strength and cold pressing strength. Through the coal briquette pyrolysis experiments, the influence of pyrolysis water and new water which were used as molding water of powdered coal respectively on coal pyrolysis conversion rate and semi-coke strength were experimentally investigated in the $3 \mathrm{~kg}$ pyrolysis experimental device. After analysis and comparison, the feasibility of lignite as pyrolysis water was gained. The quality analysis results of coal, MCPW, MCNW were shown in table 1, total water of coal sample was $25.90 \%$, volatile of air dried basis was $37.11 \%$, and the utilization efficiency could be improved by pyrolysis. The element composition and industrial analysis of MCPW, MCNW were different little, and heat value of MCPW was higher than that of MCNW.

Table 1 The quality analysis of raw coal, MCPW and MCNW

\begin{tabular}{|c|c|c|c|c|c|c|c|c|c|c|}
\hline \multirow[t]{2}{*}{ Coal sample } & \multicolumn{4}{|c|}{$\begin{array}{l}\text { Industrial analysis } \\
\qquad(w t \%)\end{array}$} & \multirow{2}{*}{$\begin{array}{c}\begin{array}{c}\text { Calorific Value } \\
\text { (kcal/kg) }\end{array} \\
\mathrm{Q}_{\mathrm{gr}, \mathrm{ad}} \\
\end{array}$} & \multicolumn{5}{|c|}{$\begin{array}{c}\text { Element analysis } \\
\text { (wt\%) }\end{array}$} \\
\hline & $\mathrm{M}_{\mathrm{ad}}$ & $\mathrm{A}_{\mathrm{ad}}$ & $\mathrm{V}_{\mathrm{ad}}$ & $\mathrm{FC}_{\mathrm{ad}}$ & & $\mathrm{S}_{\mathrm{t}, \mathrm{ad}}$ & $\mathrm{C}_{\mathrm{ad}}$ & $\mathrm{H}_{\mathrm{ad}}$ & $\mathrm{N}_{\mathrm{ad}}$ & $\mathrm{O}_{\mathrm{ad}}$ \\
\hline Raw coal & 16.33 & 7. 68 & 31.66 & 44.33 & 4683.43 & 0.16 & 53.13 & 3. 48 & 0.33 & 18.89 \\
\hline MCPW & 10.63 & 22.82 & 32.37 & 34.18 & 4548.02 & 0.67 & 50.24 & 3.41 & 1.03 & 11.20 \\
\hline MCNW & 10.18 & 22.81 & 31.85 & 35.16 & 4434.78 & 0.80 & 50.01 & 3.31 & 0.28 & 12.61 \\
\hline
\end{tabular}




\section{Experimental result}

\section{The strength of MCPW and its semi-coke}

Mechanical strength cold compressive strength of MCPW and its semi-coke、MCNW and its semi-coke were tested respectively according to determination of shatter indices of coal (GB/T 15459-2006) and determination of cold compressive strength of industrial briquette( MT/T 748-2007). The experimental results showed that compared with the semi-coke, the surface of MCPW semi-coke had more obvious cracks. The strength of MCPW and its semi-coke were shown in Table 2, the strength of MCPW had less change after being pyrolyzed, compared with MCNW. It could be seen that the oil and other components in the pyrolysis water could increase the strength of semi-coke.

Table 2 The strength of MCNW and its semi-coke

\begin{tabular}{cccccc}
\hline \multirow{2}{*}{ Coal } & \multicolumn{2}{c}{ Before pyrolysis } & & \multicolumn{2}{c}{ After pyrolysis } \\
\cline { 2 - 3 } \cline { 5 - 6 } sample & Mechanical & Compressive & & Mechanical & compressive \\
& strength(\%) & strength(N) & & strength(\%) & strength(N) \\
\hline \multirow{2}{*}{ MCPW } & 96.72 & 263.17 & & 75.42 & 242.17 \\
MCNW & 90.36 & 203.29 & 50.50 & 174.57 \\
\hline
\end{tabular}

\section{The influence of pyrolysis water on pyrolysis products of molding coal}

The distribution of pyrolysis products of MCPW and MCNW were shown in Table 3, the tar yield in pyrolysis of MCPW was $4.70 \%$ (as received basis), the tar yield in pyrolysis of MCNW was 3.39\%, and the tar yield of MCPW was 1.4 times of the tar yield of MCNW The content of light tar of MCPW was higher. It was believed that the tar yield could be increased in the pyrolysis water, and it was helpful to improve the quality of the tar.

Table 3 The influence of pyrolysis water on pyrolysis products (as received basis)

\begin{tabular}{|c|c|c|c|c|c|c|}
\hline \multirow{2}{*}{ Coal smaple } & \multicolumn{3}{|c|}{ Tar yield(wt\%) } & \multirow{2}{*}{$\begin{array}{l}\text { Water } \\
(w t \%)\end{array}$} & \multirow{2}{*}{$\begin{array}{c}\text { Gas yield } \\
\text { (wt\%) }\end{array}$} & \multirow{2}{*}{$\begin{array}{c}\text { Semi-coke } \\
\text { (wt\%) }\end{array}$} \\
\hline & Tar & Light oil & Heavy oil & & & \\
\hline MCPW & 4.70 & 3.76 & 0.94 & 19.90 & 10.68 & 64.72 \\
\hline MCNW & 3.39 & 1.36 & 2.03 & 16.75 & 15.66 & 64.20 \\
\hline
\end{tabular}

The semi-coke quality analysis of MCPW and MCNW were shown in table 4, sulfur content of the semi-coke of MCPW was 1.08 times that of MCNW, and both calorific value differences were small. The reason of higher sulfur content of the semi-coke of MCPW was caused by the pyrolysis water which contains sulfur. The calorific value of the semi-coke of MCNW was slightly higher. The pyrolysis water had little effect on the sulfur content of the char.

Table 4 The semi-coke quality analysis of MCPW and MCNW

\begin{tabular}{|c|c|c|c|c|c|c|c|c|c|c|}
\hline \multirow[t]{2}{*}{ Coal smaple } & \multicolumn{4}{|c|}{$\begin{array}{c}\text { Industrial analysis } \\
\text { (wt\%) }\end{array}$} & \multirow{2}{*}{$\begin{array}{c}\text { Calorific Value } \\
\text { ( kcal/kg) }\end{array}$} & \multicolumn{5}{|c|}{$\begin{array}{l}\text { Element analysis } \\
\qquad(w t \%)\end{array}$} \\
\hline & $\mathrm{M}_{\mathrm{ad}}$ & $\mathrm{A}_{\mathrm{ad}}$ & $\mathrm{V}_{\mathrm{ad}}$ & $\mathrm{FC}_{\mathrm{ad}}$ & & $\mathrm{S}_{\mathrm{t}, \mathrm{ad}}$ & $\mathrm{C}_{\mathrm{ad}}$ & $\mathrm{H}_{\mathrm{ad}}$ & $\mathrm{N}_{\mathrm{ad}}$ & $\mathrm{O}_{\mathrm{ad}}$ \\
\hline MCPW & 0.34 & 34.19 & 9.64 & 55.83 & 5442,62 & 0.86 & 60.59 & 2.21 & 1.32 & 0.49 \\
\hline MCNW & 0.23 & 31.58 & 9.65 & 58.54 & 5567.62 & 0.79 & 61.83 & 2.33 & 1.41 & 1.83 \\
\hline
\end{tabular}

The analysis results of crude gas component of pyrolyzed MCPW and MCNW was shown in Table 5 , The crude gas of MCPW had more $\mathrm{CH} 4$, and less $\mathrm{H}_{2} 、 \mathrm{CO}_{2} 、 \mathrm{CO} 、 \mathrm{C}_{\mathrm{n}} \mathrm{H}_{\mathrm{m}}$, and both calorific value difference were small, comparing with that of MCNW, the calorific value of crude gas of MCNW was slightly higher. 
Table 5 The analysis of crude gas component of pyrolyzed MCPW and MCNW

\begin{tabular}{ccccccc}
\hline Coal smaple & $\mathbf{H}_{\mathbf{2}}(\mathrm{V} \%)$ & $\mathbf{C O}_{\mathbf{2}}(\mathbf{V} \%)$ & $\mathbf{C H}_{\mathbf{4}}(\mathbf{V} \%)$ & $\mathbf{C O}(\mathbf{V} \%)$ & $\mathbf{C}_{\mathbf{n}} \mathbf{H}_{\mathbf{m}}(\mathbf{V} \%)$ & calorific value $\left(\mathrm{Kcal} / \mathbf{N m}^{\mathbf{3}}\right)$ \\
\hline MCPW & 13.33 & 45.68 & 25.47 & 9.67 & 5.85 & 3197.43 \\
MCNW & 11.74 & 48.45 & 22.75 & 10.40 & 6.66 & 3330.53 \\
\hline
\end{tabular}

\section{Conclusions}

By analyzing of mechanical strength, cold compressive strength and pyrolysis products, the experimental results are as follows:

1) The elemental composition and industrial analysis of MCPW and MCNW differed not quite, and the calorific value of MCPW was higher than that of MCNW.

2) Compared with MCNW, the strength ofMCPW had less change after being pyrolyzed, and it could be derived that the pyrolysis water could increase the strength of semi-coke.

3) The tar yield of MCPW was 1.4 times that of MCNW, and there was more light oil in the content of MCPW. It was considered that pyrolysis water could help to improve the quality of tar, and increase $\mathrm{CH}_{4}$ and $\mathrm{H}_{2}$ content of coal gas.

4) Sulfur content in semi-coke of MCPW was 1.08 times than that of MCNW, both calorific value differences were small, and the calorific value of MCNW was slightly higher. Water pyrolysis had little effect on the sulfur content in semi-coke.

\section{References}

[1] Ma Jian. Present status in China of coal preparation industry \& consideration on its development in theTwelfth Five-Year Plan[J]. Coal Processing \&Comprehensive Utilization, 2011, (4):1-4.

[2] Yang X.Y, Yang J, Xia H.B. Increasing oil technology status and trends of low rank coal pyrolysis, Guangzhou Chemical Industry,2012(13)

[3] Zeng C.Effects of pretreatment in steam on the pyrolysis behavior of LoyYang brown coal[J].Energy Fuels, 2006(1)

[4]Zeng C.Effects of dewatering on the pyrolysis and gasification reactivity of Victorian brown coal[J]J.Energy Fuels, 2007(2)

[6] Han Y.B, Liu G.J, Zhao H.B. Structural characteristics of low-rank coal and its pyrolysis technology development, Bulletin of the Chinese Academy of Sciences,2013(6)

[7] Ma L.Z, He P, Wang H, etc. Experiment on Zhaotong Brown Coal Pyrogenation, Journal of Kunming University of Science and Technology (Natural Science Edition), 2005(3)

[8] Wang N, Zhu S.Q, Chu M, etc. A study on the pyrolysis characters of Baori lignite and its product property, China Coal, 2010(5)

[9]LI Hong-yue. Study of the relationship between energy consumption and economic growth of China[J]. Inquiry into Economic Issues, 2012, (1): 14-19. (In Chinese)

[10] WANG Jian-guo, ZHAO Xiao-hong. Demonstration of key technologies for clean and efficient utilization of low-rank coal[J]. Bulletin of Chinese Academy of Sciences,2012, 27(3):382-388. (In Chinese)

[11]XUN Hua,HAN Jian-chun,LIU Wei. Particle size and heating rate on the low calorific value coal pyrolysis effect research[J]. Power System Engineering, 2012,28(1):13-15. (In Chinese)

[12]LV Tai,ZHANG Cui-zhen, WU Chao. Study on the effect of coal diameter and heating rate on the coal pyrolysis[J]. Coal Conversion, 2005, 28(1):17-20.(In Chinese) 